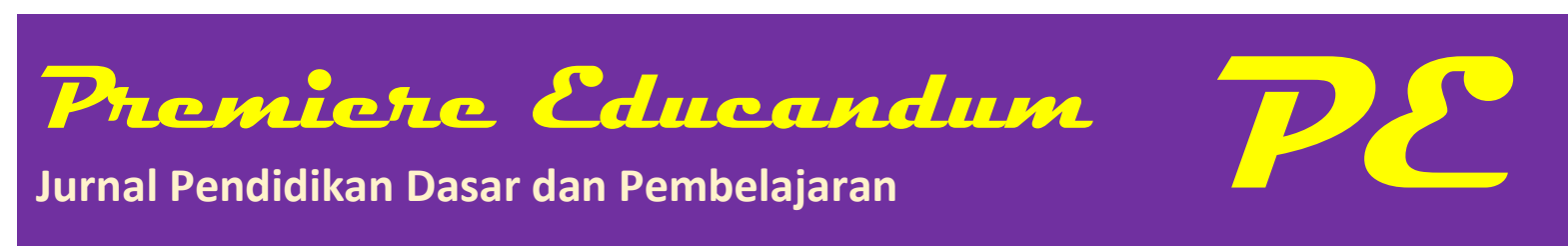

Premiere Educandum 7(2) 124 - 134 | Desember 2017

Copyright (C2017 Universitas PGRI Madiun

ISSN: 2088-5350 (Print) / 2528-5173 (Online)

Available at: http://e-journal.unipma.ac.id/index.php/PE

DOI: $10.25273 /$ pe.v7i2.1653

\title{
Pengaruh Pendekatan Cooperative Learning Tipe (TPS) Think, Pair, and Share Terhadap Hasil Belajar PKn di Sekolah Dasar
}

\author{
Sulistyani Puteri Ramadhani \\ Fakultas Keguruan dan Ilmu Pendidikan, Universitas Trilogi Jakarta, Indonesia \\ email: sulistyani@trilogi.ac.id
}

\begin{abstract}
The purpose of this study is to determine the effect of the use of cooperative learning approach type think, pair, and share on the results of learning Civics in grade V primary school students. This research was conducted at SDN Kebon Baru 10 Pagi with research sample of class V students in second semester of academic year 20162017. The sample used Simple Random Sampling technique. This research is using experimental method. The data collection technique is done using test sheet after the learning material is given test sheet to know the student's learning result of Civics, which has been tested the validity and reliability with expert justification and analyzed by normality test and homogeneity test both control class and experiment class. Normality test results show that the two classes are normally distributed. Homogeneity test results show that both classes are homogeneous. After testing the requirements analysis, then tested the hypothesis with t-test calculation. Based on the result of t-test, the null hypothesis $\left(\mathrm{H}_{0}\right)$ is rejected and the working hypothesis $\left(\mathrm{H}_{1}\right)$ is accepted. From these calculations it can be concluded that the use of cooperative learning approach type think, pair, and share have a significant effect on the results of learning Civics in grade $\mathrm{V}$ primary school students. The implications of this study are the use of cooperative learning approach of type think, pair, and share on learning Civics can be applied by teachers in order to improve student learning outcomes.
\end{abstract}

Keywords: approach, cooperative learning think, pair, and share, learning outcomes Civics

\begin{abstract}
Abstrak
Tujuan penelitian ini adalah untuk mengetahui pengaruh penggunaan pendekatan cooperative learning tipe think, pair, and share terhadap hasil belajar PKn pada siswa kelas V sekolah dasar. Penelitian ini dilaksanakan di SDN Kebon Baru 10 Pagi dengan sampel penelitian siswa kelas V pada semester II tahun pelajaran 2016-2017. Sampel penelitian menggunakan teknik Simple Random Sampling. Penelitian ini menggunakan metode eksperimen. Adapun teknik pengumpulan data dilakukan menggunakan lembar tes yang dilakukan setelah materi pembelajaran diberikan lembar tes untuk mengetahui hasil belajar PKn siswa, yang sebelumnya telah dilakukan pengujian validitas dan reliabilitas dengan justifikasi ahli dan dianalisis dengan uji normalitas dan uji homogenitas baik kelas kontrol maupun kelas eksperimen. Hasil pengujian normalitas menunjukan bahwa kedua kelas berdistribusi normal. Hasil pengujian homogenitas menunjukan bahwa kedua kelas tersebut homogen. Setelah dilakukan uji persyaratan analisis, maka dilakukan uji hipotesis dengan perhitungan uji-t. Berdasarkan hasil perhitungan uji-t maka hipotesis nol $\left(\mathrm{H}_{\mathrm{o}}\right)$ ditolak dan hipotesis kerja $\left(\mathrm{H}_{1}\right)$ diterima. Dari perhitungan tersebut maka dapat disimpulkan bahwa penggunaan pendekatan cooperative learning tipe think, pair, and share berpengaruh signifikan terhadap hasil belajar PKn pada siswa kelas V sekolah dasar. Implikasi hasil penelitian ini adalah penggunaan pendekatan cooperative learning tipe think, pair, and share pada pembelajaran PKn dapat diterapkan guru agar dapat meningkatkan hasil belajar siswa.
\end{abstract}

Kata Kunci: pendekatan, cooperative learning think, pair, and share, hasil belajar PKn 


\section{A. PENDAhuluan}

\begin{abstract}
Berdasarkan Kurikulum Tingkat Satuan Pendidikan (KTSP), PKn merupakan salah satu pelajaran yang bertujuan (1) agar peserta Berpikir secara kritis, rasional, dan kreatif dalam menanggapi isu kewarganegaraan, (2) berpartisipasi secara aktif dan bertanggung jawab, dan bertindak secara cerdas dalam kegiatan bermasyarakat, berbangsa, dan bernegara, serta anti-korupsi, berkembang secara positif dan demokratis untuk membentuk diri berdasarkan karakter-karakter masyarakat Indonesia agar dapat hidup bersama dengan bangsabangsa lainnya, (4) berinteraksi dengan bangsa-bangsa lain dalam percaturan dunia secara langsungatau tidak langsung dengan memanfaatkan teknologi informasi dan komunikasi (BSNP, 2006: 108).
\end{abstract}

Semua kemampuan yang ada didalam tujuan PKn tersebut diperlukan agar siswa mampu memperoleh, mengolah, dan memanfaatkan informasi dalam menghadapi perkembangan zaman yang semakin pesat. Kemampuan berpikir siswa dapat diperoleh tentunya melalui pendidikan dan pengajaran yang berkompetensi.

Berdasarkan pengamatan nyata di lapangan, proses pembelajaran di sekolah saat ini kurang melibatkan siswa secara aktif, terutama dalam pembelajaran PKn. Proses belajar-mengajar PKn yang dilakukan guru cenderung menggunakan metode konvensional secara monoton, sehingga suasana pembelajaran terkesan kaku karena didominasi oleh guru dan siswa menjadi pasif. Hal lain yang menjadi hambatan selama ini dalam pembelajaran Pendidikan Kewarganegaraan (PKn) adalah kurang dikemasnya pembelajaran dengan metode atau model pembelajaran yang menarik, menantang, dan menyenangkan sehingga pembelajaran pengetahuan sosial cenderung membosankan dan kurang menarik minat para siswa sehingga prestasi atau hasil belajar siswa kurang memuaskan. Agar pembelajaran PKn menjadi pembelajaran yang lebih mengaktifkan siswa dalam proses pembelajaran, dapat dilakukan melalui berbagai cara. Salah satu cara atau metode yang cukup efektif dan dianggap cocok diterapkan dalam pendidikan kewarganegaraan adalah melalui pendekatan cooperative learning.

Cooperative learning dapat didefinisikan sebagai sistem kerja atau belajar kelompok yang terstruktur. Yang termasuk didalam struktur ini ada lima unsur pokok (Johnson\&Johnson 1994) dan Sutton (1992), yaitu: (1) saling ketergantungan positif, (2) tanggung jawab individual, (3) interaksi personal, (4) keahlian bekerja sama, (5) proses kelompok (Trianto, 2010: 60). Selain itu Stahl (1994) dalam buku solihatin mengatakan bahwa model pembelajaran cooperative learning menempatkan siswa sebagai bagian dari suatu sistem kerja sama dalam mencapai suatu hasil yang optimal dalam belajar. Model pembelajaran ini berangkat dari asumsi mendasar dalam kehidupan masyarakat, yaitu "getting better together", atau "raihlah yang lebih baik secara bersama-sama" (Etin Solihatin dan Raharjo, 2007: 5). Aplikasi cooperative learning di dalam kelas 
mengetengahkan realita kehidupan masyarakat yang dirasakan dan dialami oleh peserta didik dalam kehidupan sehariharinya dengan bentuk yang disederhanakan dalam kehidupan kelas. Model pembelajaran kooperatif memandang bahwa keberhasilan dalam belajar bukan semata-mata diperoleh dari guru, melainkan bisa juga dari pihak lain yang terlibat dalam pembelajaran itu, yaitu teman sebaya. Salah satu tipe pembelajaran kooperatif yang dapat diaplikasikan secara sederhana di dalam kelas yaitu tipe Think, Pair, and Share (TPS).

Metode pembelajaran think, pair, and share merupakan salah satu tipe pembelajaran dengan menggunakan pendekatan cooperative learning. Melalui pendekatan pembelajaran ini siswa dilatih untuk banyak berpikir dan saling tukar pendapat baik dengan teman sebangku ataupun dengan teman sekelas, sehingga dapat meningkatkan hasil belajar ranah kognitif siswa karena siswa dituntut untuk mengikuti proses pembelajaran agar dapat menjawab setiap pertanyaan dan berdiskusi.

Berdasarkan hal-hal positif yang diharapkan dalam penggunaan pendekatan ini dan melihat pada umumnya pembelajaran masih kurang melibatkan siswa secara aktif, maka perlu diadakan penelitian di kelas untuk membuktikan bahwa melalui pendekatan cooperative learning tipe think, pair, and share dapat mempengaruhi hasil belajar siswa kelas $\mathrm{V}$ Sekolah Dasar dalam pembelajaran Pendidikan Kewarganegaraan.

Berdasarkan uraian di atas, maka perumusan masalahnya adalah: "Adakah pengaruh pendekatan cooperative learning tipe think, pair, and share terhadap hasil belajar PKn siswa kelas V SD Negeri di Wilayah Gugus V Kecamatan Tebet Jakarta Selatan?".

Belajar adalah kegiatan yang berproses dan merupakan unsur yang sangat fundamental dalam penyelenggaraan setiap jenis dan jenjang pendidikan (Muhibbin, 2003: 63).Ini berarti, bahwa berhasil atau gagalnya pencapaian tujuan pendidikan itu amat bergantung pada proses belajar yang dialami siswa baik ketika ia berada di sekolah maupun di lingkungan rumah atau keluarganya sendiri. Belajar diartikan sebagai suatu proses usaha yang dilakukan seseorang untuk memperoleh suatu perubahan tingkah laku yang baru secara keseluruhan, sebagai hasil pengalamannya sendiri dalam interaksi dengan lingkungannya (Slameto, 2003: 2). Dalam hal ini yang dimaksud belajar adalah usaha untuk mencapai kepandaian atau ilmu yang belum dipunyai sebelumnya. Sehingga dengan belajar itu manusia menjadi tahu, memahami, mengerti, dapat melaksanakan dan memiliki pengetahuan tentang sesuatu. Dengan belajar, manusia mengalami perubahan-perubahan yang dapat mengembangkan semua potensi yang ada pada dirinya. Belajar adalah serangkaian kegiatan jiwa raga untuk memperoleh suatu perubahan tingkah laku sebagai hasil dari pengalaman individu dalam interaksi dengan lingkungannya yang menyangkut kognitif, afektif, dan psikomotor (Syaiful Bahri, 2002: 13). Perubahan tingkah laku seseorang dapat dilihat secara kongkrit atau dapat dilihat. Pengamatan ini dapat 
diwujudkan dalam bentuk gerakan yang dilakukan terhadap suatu obyek yang dikerjakannya. Seorang guru memberikan perintah kepada siswa untuk melakukan kegiatan praktek merupakan stimulus dan siswa dengan menggunakan pemikirannya melakukan kegiatan praktek merupakan respon yang hasilnya langsung dapat diamati.

Berdasarkan beberapa pengertian mengenai belajar, maka dapat disimpulkan bahwa belajar adalah suatu proses usaha yang dilakukan seseorang untuk memperoleh pengetahuan, perubahan tingkah laku, serta keterampilan, baik melalui pengalaman sendiri maupun pengalaman yang berasal dari luar. Ada tidaknya kegiatan belajar dapat dilihat dari ada tidaknya perubahan tingkah laku yang diakibatkan oleh pengalaman yang akan mendapat sebuah hasil belajar. Perubahan belajar tersebut adalah perubahan dari tidak tahu menjadi tahu.

Dalam proses belajar mengajar salah tujuan yang diharapkan yaitu perubahan tingkah laku yang dapat dikuasai oleh siswa setelah menerima atau menempuh pengalaman belajarnya dan untuk mengetahui sejauh mana tujuan yang telah ditetapkan itu tercapai atau tidak. Bila seseorang seseorang telah belajar akan terjadi perubahan tingkah laku pada orang tersebut, dari tidak tahu menjadi tahu, tingkah laku manusia terdiri atas sejumlah aspek hasil belajar akan tampak pada setiap perubahan pada aspek-aspek lain : Pengetahuan, emosional, pengertian, hubungan sosial, kebiasaan jasmani, keterampilan, etis atau budi pekerti, sikap (Oemar Hamalik, 2003: 27). Hasil belajar adalah perubahan tingkah laku yang terlihat beberapa aspek, antara lain pengetahuan, emosional, pengertian, hubungan sosial, kebiasaan, jasmani, keterampilan, etis/budi pekerti, apresiasi, dan sikap (Nana Sudjana, 2008: 2). Hasil belajar dari pengertian ini adalah perubahan tingkah laku yang dapat dilihat dari aspek pengetahuan, keterampilan, dan sikap.

PKn merupakan mata pelajaran yang memfokuskan pada pembentukan diri yang beragam dari segi agama, sosio kultural, usia, dan suku bangsa untuk menjadi warga Negara yang cerdas, terampil, dan berkarakter sesuai dengan yang diamanatkan oleh nilai-nilai pancasila dan UUD 1945. Maka dari itu diperlukan pemanfaatan sumber belajar PKn yang tidak saja terpaku pada buku tetapi juga pada media-media yang ada dan sumbersumber lainnya dari lingkungan. Menteri Pendidikan Nasional melalui Keputusan Direktur Jenderal Perguruan Tinggi No. 267/Dikti/Kep/2000, merumuskan Pendidikan Kewarganegaraan adalah pendidikan yang dirancang dengan maksud agar peserta didik memiliki pengetahuan dan kemampuan dasar tentang hubungan antara warga negara dengan negaranya sebagai bekal menjadi warga negara yang dapat diandalkan oleh bangsa dan negaranya (H. E. Hasan Saleh, 2009: 30). Rumusan tersebut sesuai dengan Pasal 32 ayat (2) Undang-undang Nomor 2 Tahun 1989 tentang Sistem Pendidikan Nasional (Sisdiknas) bahwa Pendidikan Kewarganegaraan merupakan usaha untuk membekali peserta didik dengan pengetahuan dan kemampuan dasar 
berkenaan dengan hubungan antara warga negara dengan negara serta pendidikan pendahuluan bela negara agar menjadi warga negara yang dapat diandalkan oleh bangsa dan negara (Tim Dosen Kewarganegaraan UNJ, 2012: 1). Dalam kurikulum SD tahun 2006 (KTSP) khususnya mata pelajaran Pendidikan Kewarganegaraan (PKn) bertujuan agar peserta didik memiliki kemampuan sebagai berikut; (1) agar peserta Berpikir secara kritis, rasional, dan kreatif dalam menanggapi isu kewarganegaraan, (2) berpartisipasi secara aktif dan bertanggung jawab, dan bertindak secara cerdas dalam kegiatan bermasyarakat, berbangsa, dan bernegara, serta anti-korupsi,

berkembang secara positif dan demokratis untuk membentuk diri berdasarkan karakter-karakter masyarakat Indonesia agar dapat hidup bersama dengan bangsabangsa lainnya, (4) berinteraksi dengan bangsa-bangsa lain dalam percaturan dunia secara langsungatau tidak langsung dengan memanfaatkan teknologi informasi dan komunikasi (BSNP, 2006: 108). Dengan demikian, tujuan Pendidikan Kewarganegaran, di samping agar peserta didik memahami dan mampu melaksanakan hak dan kewajibannya sebagai warga negara yang bertanggung jawab, juga untuk memupuk sikap dan perilaku peserta didik yang sesuai dengan nilai-nilai kejuangan bangsa yang cinta tanah air serta rela berkorban bagi nusa dan bangsanya.

Djahiri dalam bukunya Isjoni menyatakan bahwa "Cooperative learning sebagai pembelajaran kelompok kooperatif yang menuntut diterapkannya pendekatan belajar siswa yang sentris, humanistik, dan demokratis yang disesuaikan dengan kemampuan siswa dan lingkungan belajarnya" (Isjoni, 2007: 15). Dengan demikian maka pembelajaran kooperatif mampu membelajarkan diri dalam kehidupan siswa baik di kelas atau sekolah. Selain itu lingkungan belajarnya dapat mengembangkan potensi diri siswa.

Lie dalam bukunya Isjoni menyebutkan cooperative learning dengan istilah pembelajaran gotong royong, yaitu sistem pembelajaran yang memberi kesempatan kepada peserta didik untuk bekerja sama dengan siswa lainnya dalam tugas yang terstruktur (Isjoni, 2007: 16). Jadi, cooperative learning hanya dapat berjalan jika sudah terbentuk suatu kelompok atau suatu tim yang di dalamnya siswa bekerja secara terarah untuk mencapai tujuan yang sudah ditentukan. Menurut Eggen and Kauchak dalam Trianto menyatakan pembelajaran cooperative merupakan sebuah kelompok strategi pengajaran yang melibatkan siswa bekerja secara berkolaborasi untuk mencapai tujuan bersama (Trianto, 2007: 5). Cooperative learning adalah suatu pendekatan belajar mengajar yang mengedepankan pada sikap atau perilaku bersama dalam bekerja atau membantu diantara sesama dalam struktur kerja sama yang teratur dalam kelompok, yang terdiri dari empat orang atau lebih (Anita Lie, 2005: 31). Hubungan kerja seperti itu memungkinkan timbulnya persepsi yang positif tentang apa yang dapat dilakukan siswa untuk mencapai keberhasilan belajar, berdasarkan kemampuan dirinya secara individu dan andil dari anggota kelompok 
lain selama belajar bersama dalam kelompok. Pendekatan cooperative learning memiliki berbagai macam tipe dalam pembelajaran, salah satu tipe pembelajaran kooperatif yang dipakai dalam penelitian ini adalah tipe think, pair, and, share.

Think. Pair, and Share (TPS) ini pertama kali dikembangkan oleh Frank Lyman dan rekan-rekannya di univesitas Maryland. "TPS merupakan salah satu metode pembelajaran dari model cooperative learning, dimana sistem belajar kelompok dan debriefing secara individual dan kelompok dalam model cooperative learning yang mendorong timbulnya tanggung jawab sosial dan individual siswa, berkembangnya sikap ketergantungan yang positif, mendorong peningkatan dan kegairahan belajar siswa, serta pengembangan dan ketercapaian kurikulum (Frank Lyman, http//curry.edschool. virginia.edu). Thinkpair-share merupakan suatu cara yang efektif untuk membuat variasi suasana pola diskusi kelas. Diskusi membutuhkan pengaturan untuk mengendalikan kelas secara keseluruhan, dan prosedur yang digunakan dalam Think, Pair, and Share dapat memberikan siswa lebih banyak waktu berpikir untuk merespon, dan saling membantu. Guru hanya melengkapi penyajian singkat atau siswa membaca tugas, atau situasi yang menjadi tanda tanya (Trianto, 2007: 61). Beberapa siswa membutuhkan kesempatan untuk melemparkan gagasan kepada orang lain agar dapat belajar secara optimal. Hal ini sesuai dengan pendapat yang dikemukakan oleh Thomas Armstrong "Berbagi rasa dengan teman sekelas ini juga dapat dikembangkan menjadi mengajari teman sebaya (siswa melatih atau mengajarkan materi tertentu kepada siswa lain (Thomas Armstrong, 2004: 120). Dengan berbagi rasa siswa dapat membahas bersama topik yang sedang dipelajari. Siswa saling mengungkapkan pendapatnya sehingga terjalin interaksi antar siswa.

Untuk lebih jelasnya berikut adalah langkah - langkah pembelajaran menggunakan think-pair-share; (1) guru menyampaikan pokok materi dan kompetensi yang ingin dicapai, (2) siswa diminta membentuk kelompok kecil tiap kelompok terdiri atas 4 sampai 6 orang (usahakan genap, karena akan dipasangpasangkan).(3) siswa diminta untuk berpikir dan menjawab pertanyaan yang disampaikan guru terkait dengan pokok materi (4) siswa diminta untuk berpasangpasangan atau duduk berhadapan saling mengemukakan hasil pemikirannya terhadap pertanyaan yang diberikan oleh guru (5) kemudian pasangkan kembali ke kelompoknya dan tiap anggota kelompok diberi kesempatan untuk mengemukakan hasil pemikirannya (6) guru memimpin diskusi dan tiap kelompok diberi kesempatan untuk mengemukakan hasil diskusinya, (7) berawal dari kegiatan tersebut mengarah pada pembicaraan pokok permasalahan dan guru menambahkan materi yang belum diungkap para siswa (Fogarty dan Robin).

Salah satu keunggulan dari metode pembelajaran TPS adalah mudah untuk diterapkan pada berbagai tingkat kemampuan berpikir dan dalam setiap kesempatan. Siswa diberi waktu lebih 
banyak berpikir, menjawab, dan saling membantu satu sama lain. Prosedur yang digunakan juga cukup sederhana. Bertanya kepada teman sebaya, dan berdiskusi berpasangan atau

Dengan demikian dapat disimpulkan bahwa Think, Pair, and Share merupakan suatu metode pembelajaran yang diajarkan kepada siswa untuk berpikir kreatif dalam merespon pertanyaan setelah itu mereka saling berbagi jawaban dengan pasangannya kemudian dengan keseluruhan kelas.

\section{B. METODE PENELITIAN}

Penelitian ini dilaksanakan di SDN Kebon Baru 10 Pagi Kecamatan Tebet Jakarta Selatan. Subyek dalam penelitian ini adalah siswa kelas V semester genap tahun pelajaran 2016/2017 sebanyak 37 siswa. Kolaborator dalam penelitian ini adalah guru kelas V SDN Kebon Baru 10 Pagi.

Metode yang digunakan pada penelitian ini adalah eksperimen, yaitu sebuah metode penelitian yang digunakan untuk mencari pengaruh perlakuan tertentu terhadap yang lain dalam kondisi yang terkendalikan (Sugiyono, 2011: 107). Penelitian ini dilaksanakan menggunakan kelompok yang terdiri atas dua kelompok yang sama atau homogen. Kelompok pertama adalah kelompok eksperimen, yaitu kelompok yang diajarkan dengan menggunakan pendekatan cooperative learning tipe think, pair, and share. Kelompok kedua adalah kelompok kontrol/ pengendali yang diajarkan dengan menggunakan pendekatan konvensional.
Desain penelitian yang digunakan dalam penelitian adalah Posttest-Only Control Design. Desain penelitian ini mengelompokkan subjek secara acak/ random ( $\mathrm{R})$, adanya posttest kelompok eksperimen $\left(\mathrm{O}_{2}\right)$, dan adanya posttest kelompok kontrol $\left(\mathrm{O}_{4}\right)$. Kelompok eksperimen memperoleh treatment dengan pendekatan cooperative learning tipe think, pair, and share $\left(\mathrm{Y}_{\mathrm{E}}\right)$ sedangkan kelompok kontrol memperoleh treatment dengan pendekatan konvensional $\left(\mathrm{Y}_{\mathrm{K}}\right)$. Desain ini digambarkan sebagai berikut (Sugiyono, 2011: 112)

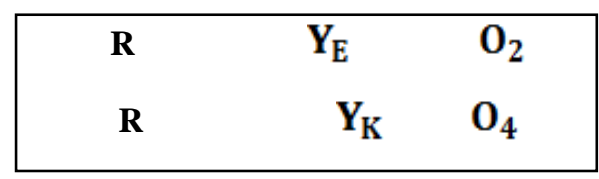

Gambar 1. Posttest-Only Control Design

Populasi adalah totalitas semua nilai yang mungkin, baik hasil menghitung maupun pengukuran, kuantitatif ataupun kualitatif, daripada karakteristik tertentu mengenai sekumpulan obyek yang lengkap dan jelas (Sudjana, 2002: 161). Populasi target dalam penelitian ini adalah siswasiswi kelas V SD Negeri di Wilayah Gugus V Kecamatan Tebet, Jakarta Selatan, yang terdiri dari SDN Kebon Baru 10 Pagi, SDN Kebon Baru 09 Pagi, SDN Kebon Baru 07 Pagi, SDN Kebon Baru 03 Pagi, dan SDN Kebon Baru 01 Pagi. Adapun Populasi terjangkau dalam penelitian ini adalah siswa-siswi kelas V di Sekolah Dasar yang memiliki kelas $\mathrm{V}$ pararel di 
Wilayah Gugus V Kecamatan Tebet, Jakarta Selatan.

Sampel adalah bagian dari jumlah dan karakteristik yang dimiliki oleh populasi tersebut. Bila populasi besar, dan peneliti tidak mungkin mempelajari semua yang ada pada populasi maka peneliti dapat menggunakan sampel yang diambil dari populasi itu (Sugiyono, 2011: 132). Dalam penelitian ini terdapat populasi yang homogen, maka untuk mendapatkan sampel yang representatif digunakan teknik Simple Random Sampling. Teknik simple random sampling merupakan cara pengambilan sampel dengan cara memilih salah satu atau beberapa kelompok secara acak sebagai sampel dengan cara pengundian. Dari hasil pengundian yang dilakukan di SD Negeri yang ada di Wilayah Gugus V Kecamatan Tebet, diperoleh SDN Kebon Baru 10 Pagi Jakarta Selatan sebagai sampel dalam penelitian ini. Selanjutya dilakukan pengundian kembali untuk menentukan kelas eksperimen dan kelas kontrol. Dari hasil pengundian diperoleh kelas V-A sebagai kelas kontrol dan kelas V-B sebagai kelas eksperimen. Dari masingmasing kelompok ini dipilih sebanyak 30 orang siswa menggunakan teknik simple random sampling.

Teknik pengumpulan data yang digunakan dalam penelitian ini adalah ujian atau tes (test) yang dilakukan setelah materi pembelajaran diberikan dengan menggunakan pendekatan cooperative learning tipe think, pair, and share.

Secara konseptual hasil belajar PKn adalah segala ilmu pengetahuan yang telah diperoleh siswa baik adanya perubahan sikap dan peningkatan kemampuan serta keterampilan siswa setelah menerima atau menyelesaikan pengalaman belajar dan memiliki arti yang sangat penting guna menjadikan siswa sebagai warga negara yang berkarakter dalam bermasyarakat, berbangsa, dan bernegara.

Hasil belajar PKn dapat diketahui dengan melakukan tes sebagai tolak ukur. Tes tersebut berbentuk pilihan ganda dengan empat pilihan jawaban yaitu: $a, b$, c, dan d sebanyak 30 butir soal. Untuk jawaban benar diberi skor satu dan untuk jawaban salah diberi skor nol.

Pilihan jawaban yang dibuat pada soal terdiri dari empat pilihan yaitu: a, b, c, dan d. Diantara keempat pilihan jawaban tersebut terdapat satu jawaban yang benar dan tiga jawaban lainnya sebagai pengecoh. Hasil belajar dilakukan dengan menggunakan ranah kognitif yang difokuskan pada aspek mengingat (C1), memahami (C2), menerapkan (C3), dan menganalisis (C4) tentang materi "Menghargai dan Menaati Keputusan Bersama", di kelas V Sekolah Dasar semester II. Butir soal yang diberikan mengacu pada Kurikulum Tingkat Satuan Pendidikan. Sedangkan rentang skor yang digunakan adalah 0 sampai 100 sehingga apabila seorang siswa menjawab sebanyak B butir dengan benar dari 30 butir soal yang diujikan, maka skor yang diperoleh adalah:

$$
\mathrm{Y}=\frac{\mathrm{B}}{\mathrm{N}} \mathrm{x} \quad 100
$$

Keterangan:

$\mathrm{Y}=$ Skor yang diperoleh siswa 
$\mathrm{B}=$ Jumlah butir soal dijawab dengan benar

$\mathrm{N}=$ Jumlah butir soal yang diujikan

Untuk menguji tingkat keterpercayaan dan keabsahan data yang diperoleh dalam penelitian ini dilakukan pengujian dengan menggunakan uji validitas dan uji reliabilitas.

Validitas butir soal untuk hasil belajar PKn yang berbentuk pilihan ganda diuji dengan menggunakan rumus Korelasi Poin Biserial $\left(\gamma_{\mathrm{pbi}}\right)$ (Suharsimi Arikunto, 2009: 79).

Reliabilitas adalah kestabilan butir soal yang diperoleh ketika diuji ulang dengan tes yang sama pada situasi yang berbeda atau dari satu pengukuran ke pengukuran lainnya (Sugiyono, 2011, 354). Rumus yang digunakan untuk menghitung reliabilitas pada penelitian ini adalah rumus dari Kuder dan Richardson.

Uji persyaratan analisis merupakan prosedur sebuah penelitian yang digunakan untuk memproses data agar data mempunyai makna untuk menjawab masalah dalam penelitian ini dan menguji hipotesis. Data yang telah diperoleh kemudian dianalisis dengan statistik deskriptif dan inferensial. Analisis statistik deskriptif digunakan untuk mengetahui kecenderungan pamusatan data (mean, median, dan modus), kecenderungan penyebaran data (rentangan dan simpangan baku) serta pembuatan tabel frekuensi dan diagram histogram. Sedangkan statistik inferensial digunakan untuk menguji hipotesis dan membuat generalisasi.
Uji normalitas yang digunakan dalam penelitian ini adalah uji Lilliefors. Uji ini dilakukan untuk mengetahui apakah data populasi berdistribusi normal atau tidak berdasarkan data yang diperoleh. Uji homogenitas yang digunakan dalam penelitian ini adalah uji F. Setelah data diuji normalitas dan homogenitsanya maka selanjutnya data dianalisis dengan menggunakan Uji-t.

\section{HASIL \& PEMBAHASAN}

Berdasarkan penelitian terhadap hasil belajar PKn siswa yang menggunakan pendekatan cooperative learning tipe think, pair, and share $(Y)$, data yang terkumpul diperoleh nilai tertinggi 96 dan nilai terendah 62 , nilai rata-rata 79,83 dengan simpangan baku 9,08 dan varians 82,48. Nilai median 76,07 dan modus 82,07. Berdasarkan hasil penelitian hasil belajar PKn siswa yang menggunakan pendekatan konvensional $\left(\mathrm{Y}_{2}\right)$, data yang terkumpul diperoleh skor tertinggi 92 dan terendah 50 , nilai rata-rata 68,53 dengan simpangan baku 9,72 dan varians 94,46 , nilai median 69,43 dan modus 67,7. Berdasarkan uji normalitas pada hasil belajar PKn yang menggunakan pendekatan cooperative learning tipe think, pair, and share, diperoleh harga $L_{\text {hitung }}$ sebesar $(0,0891)$. Pada taraf signifikansi $\propto=0,05$ dalam tabel Liliefors dengan sampel $\mathrm{n}=30$ diperoleh $\mathrm{L}_{\text {tabel }}$ sebesar 0,161 . Jadi, dapat disimpulkan bahwa $\mathrm{L}_{\text {hitung }}$ lebih kecil daripada $\mathrm{L}_{\text {tabel }}(0,0891<0,161)$. Oleh karena itu, hipotesis nol yang menyatakan sampel berdistribusi normal dapat diterima. 
Uji normalitas hasil belajar PKn dengan menggunakan pendekatan konvensional, diperoleh harga $\mathrm{L}_{\text {hitung }}$ sebesar $(0,1562)$ Pada taraf signifikansi $\propto$ $=0,05$ dalam tabel Liliefors dengan sampel $\mathrm{n}=30$ diperoleh $\mathrm{L}_{\text {tabel }}$ sebesar 0,161 Jadi, dapat disimpulkan bahwa $\mathrm{L}_{\text {hitung }}$ lebih kecil daripada $\mathrm{L}_{\text {tabel }}(0,1562<0,161)$. Oleh karena itu, hipotesis nol yang menyatakan sampel berdistribusi normal dapat diterima.

Berdasarkan hasil perhitungan uji homogenitas diperoleh $F_{\text {hitung }}(1,14)$, sedangkan $F_{\text {tabel }}(0,05(29,29))=1,90$. Jika dibandingkan, maka $F_{\text {hitung }}$ lebih kecil $F_{\text {tabel }}$ atau $1,14<1,90$. Hal ini berarti $\mathrm{H}_{0}$ diterima. Dengan demikian dua kelompok siswa yakni hasil belajar PKn siswa dengan menggunakan pendekatan cooperative learning tipe think, pair, and share $\left(\mathrm{K}_{\mathrm{E}}\right)$ dan kelompok lain hasil belajar PKn siswa dengan menggunakan pendekatan konvensional $\left(\mathrm{K}_{\mathrm{K}}\right)$ adalah homogen.

Berdasarkan perhitungan uji t yaitu siswa yang menggunakan pendekatan cooperative learning tipe think, pair, and share dengan siswa yang menggunakan pendekatan konvensional, diperoleh $t_{\text {hitung }}$ sebesar $(4,65)$ sedangkan $t_{\text {tabel }}$ sebesar 2,02. Berdasarkan hasil perhitungan tersebut maka dapat disimpulkan bahwa thitung lebih besar daripada $t_{\text {tabel }}(4,65>2,02)$. Ini berarti bahwa hipotesis yang menyatakan bahwa terdapat perbedaan hasil belajar PKn antara siswa yang diajar menggunakan pendekatan cooperative learning tipe think, pair, and share dengan siswa yang menggunakan pendekatan konvensional.

\section{SIMPULAN}

Berdasarkan hasil penelitian dengan menggunakan uji-t diketahui bahwa $t_{\text {hitung }}=4,65$ serta $t_{\text {tabel }}$ dengan $\left(\mathrm{n}_{1}+\mathrm{n}_{2}\right)-2=58$ dan taraf signifikansi $\propto=$ 0,05 adalah 2,02 maka $t_{\text {hitung }}>t_{\text {tabel }}$, maka $\mathrm{H}_{0}$ ditolak dan $\mathrm{H}_{1}$ diterima, yang berarti bahwa terdapat perbedaan antara hasil belajar PKn siswa yang menggunakan pendekatan cooperative learning tipe think, pair, and share dengan yang menggunakan pendekatan konvensional.

Berdasarkan analisis hasil penelitian di atas maka dapat disimpulkan bahwa penggunaan pendekatan cooperative learning tipe think, pair, and share berpengaruh signifikan terhadap hasil belajar PKn siswa kelas V Sekolah Dasar.

\section{DAFTAR RUJUKAN}

Arikunto, S. (2008). Dasar-dasar Evaluasi Pendidikan. Jakarta: PT. Bumi Aksara.

Arikunto, S. (2010). Prosedur Penelitian Suatu Pendekatan Praktik. Jakarta: Rineka Cipta.

Armstrong, T. (2004). Menerapkan Multiple Intelligences di Sekolah. Jakarta: PT. Mizan Pustaka.

BSNP. (2006). Standar Isi Untuk Satuan Pendidikan Dasar dan Menengah Standar Kompetensi dan Kompetensi Dasar. Jakarta: Depdiknas.

C. Laura, Strategies for Reading to Learn. (2001) http//olc.spsd.sk.ca. Diakses pada tanggal 12 Desember 2016 Pukul 09.10 WIB 
Djamarah, S. B. (2002). Psikologi Belajar. Jakarta: Rineka Cipta.

Djamarah, S. B. \& Aswan Z. (1995). Strategi Belajar Mengajar. Jakarta: PT.Rineka Cipta.

Frank Lyman, Think, Phair and Share. 1981,http//curry.edschool.virginia .ed, (Diakses pada tanggal 12 Desember 2016 pukul 09.30 WIB).

Hakim, L. (2008). Perencanaan Pembelajaran. Bandung: CV Wacana Prima.

Hamalik, O. (2003). Proses Belajar Mengajar. Jakarta: Bumi Aksara.

Isjoni. (2007). Cooperative Learning. Bandung: Alfabeta.

Lie, A. (2005). Cooperative Learning. Jakarta: Grasindo.

Mikhael, Mali, \& Benjamin. (2011). Civic Education Upaya Mengembalikan Episteme Politik. Jakarta: Fidei Press.

Muhibbin. (2003). Psikologi Belajar. Jakarta: Raja Grafindo Persada.

Purwanto, N. (2007). Psikologi Pendidikan. Bandung: PT. Remaja Rosdakarya.

Riduwan (2008). Belajar Mudah Untuk Guru, Karyawan, dan Peneliti Pemula. Bandung: Alfabeta.

Saleh, H. E. (2009). Pendidikan Kewarganegaraan (Civic Education). Jakarta : Audi Grafika.

Slamento. (2003). Belajar dan Faktorfaktor Yang Mempengaruhinya. Jakarta: Rineka Cipta.

Solihatin, E. \& Raharjo. (2007). Cooperative Learning Analisis
Model Pembelajaran IPS. Jakarta: Bumi Aksara.

Sudjana, N. (2002). Metode Statistika. Bandung: Tarsito.

Sudjana, N. (2008). Penilaian Hasil Proses Belajar Mengajar. Bandung: Remaja Rosdakarya.

Sugiyono. (2009). Metode Penelitian Pendidikan. Bandung: Alfabeta.

Tim Dosen Kewarganegaraan Universitas Negeri Jakarta. (2012). Pendidikan Kewarganegaraan. Jakarta: UNJ.

Trianto. (2007). Tipe Pembelajaran Terpadu dalam Teori dan Praktik. Surabaya: Prestasi Pustaka Publisher.

Trianto. (2010). Mendesain Type Pembelajaran Inovatif Progresif. Jakarta:Kencan. 